\title{
単糖およびオリゴ糖の配位子交換モードによる 液体クロマトグラフィー/質量分析法
}

\section{Ligand Exchange Liquid Chromatography/Mass Spectrometry of Mono- and Oligosaccharides}

\author{
中尾千予視 1 蒲生啓司 ${ }^{1 *}$ ・菱田勝巳 ${ }^{2}$ 和田啓男 ${ }^{2}$ \\ Chiyomi Nakao, ${ }^{1}$ Keiji Gamoh, ${ }^{1 *}$ Katsumi Hishida, ${ }^{2}$ and Hiroo Wada ${ }^{2}$ \\ 1 高知大学教育学部理科教育講座 Faculty of Education, Kochi University, Kochi, JAPAN \\ 2 信和化工株式会社 Shinwa Chemical Industry Ltd., Kyoto, JAPAN
}

\begin{abstract}
A technique was developed for ligand-exchange liquid chromatography/mass spectrometry (LC/MS) of mono- and oligosaccharides. A mixture of seven monosaccharides, four disaccharides, and two trisaccharides was successfully analyzed by using an improved ligand-exchange column comprising a semi-rigid styrenedivinylbenzene copolymer-based Ca-type cation-exchange resin (ULTRON PS-80C/10S) in conjunction with electrospray-ionization mass spectrometry (ESI-MS). Water was used as a mobile phase to separate the saccharides within $12 \mathrm{~min}$. The ESI interface was used in negative-ion mode for LC/MS and produced reasonable signals from negative molecular ions $\left([\mathrm{M}-\mathrm{H}]^{-}\right)$of the saccharides. The effect of aqueous ammonia used as an additive in the eluent was also examined. The detection sensitivities of the saccharides increased when aqueous ammonia was used as an additive at a concentration of 2 vol\%. The effects of separation and ionization parameters, column temperature, and cone voltage on the sensitivity and linearity were examined. Linear plots of peak area versus concentration were obtained for MS detection over the range $5-1000 \mu \mathrm{M}\left(r^{2}=0.951-0.999\right)$ for each saccharide. The detection limits of the target saccharides calculated at a signal-to-noise ratio of 3 ranged from 3.7 to $17.1 \mathrm{ng}$. The reproducibility of the retention times was $0.66-1.2 \%$ and that of the peak areas was $0.96^{-}$ $2.86 \%$. A comparison of these results with those obtained with a normal-phase semimicro aminopropyl column confirmed the usefulness of ligand-exchange LC/MS of mono- and oligosaccharides. The newly developed method was applied in the determination of mono- and oligosaccharides extracted from seaweed and hydrolyzed by a hydrothermal reaction.
\end{abstract}

\section{1. 序論}

近年，核酸やタンパク質に次ぐ第三の鎖状生命分子とし て糖鎖分子が注目されており, タンパク質の機能高度化に 重要な役割を果たしていることが明らかになってきた。か つて糖は，主にエネルギーや組織を形成する要素ととらえ られていたが，現在では糖鎖分子が細胞表層のタンパク質 や脂質と連結している様子が明らかになり，こうした分子 が細胞に与える影響や役割が医療や薬学などの分野で注目 されてきている．糖鎖研究を行ううえで糖鎖分子の構造解 析は必要不可欠で, 高速液体クロマトグラフィー (HPLC) による多次元マッピングや電気泳動 ${ }^{1)}$, 質量分析や多次元 核磁気共鳴 (NMR) などを用いた解析法が確立されつつあ

* Correspondence to: Keiji GAmoH, Faculty of Education, Kochi University, 2-5-1 Akebonocho, Kochi 780-8520, JAPAN, e-mail: kgamoh@cc.kochi-u.ac.jp

蒲生啓司, 高知大学教育学部理科教育講座, $\mathbf{\top} 780-8520$ 高知市曙町 $2-5-1$
$り^{2)}$, 生体内の糖タンパク質の解析に関する研究むいくつ か報告されている31,4).一方で, 天然にはセルロースやペク チンなどの多糖類が存在しており, 植物から抽出したぺク チンの構成糖の分析による構造解析の研究などがいくつか 報告されている5),6). しかしながら, 糖鎖分子の構造や機能 性はいまだ明らかにされていない点が多く, 糖鎖研究を行 うにあたって, 糖類の簡便かつ高感度な分析法の開発およ び改良が早急に求められている.

糖は水酸基を多くもつ構造のため, ガスクロマトグラ フィー (GC) 法での分析の際には, メチル化などの誘導体 化の処理が必要となる7). HPLC 法での糖分析においては, 糖の高感度検出が容易ではないため, 分離法とともに検出 法にさまざまな方法が用いられてきた，従来から糖分析に 用いられている分離法には, 主として配位子交換, 順相分 配および陰イオン交換法などがあるが，糖類を誘導体化し た後に逆相分配法で分析している報告あある ${ }^{8)}$. 検出法と しては, 主として示差屈折率, 電気化学および蛍光検出法 などが用いられてきた. さらに最近では, 検出感度の向上 
を目的として，液体クロマトグラフィー/質量分析 (LC/ MS) 法を用いた分析む行わ机ており, 糖類の微量分析法と して注目されている。誘導体化法と LC/MS 法を組合せた 方法では，例えば Suzuki らは，2-アミノピリジン (2-AP) をはじめとする数種類の試薬でオリゴ糖の誘導体化を行 い，エレクトロスプレーイオン化 (ESI) 法または高速電子 衝撃イオン化 (FAB-LC/MS) 法による検出感度を比較し, 数十〜数百 $\mathrm{pmol}$ の検出下限を得ている早. また Kawasaki らは，2-AP の同位体を内部標準として用いることに よって, さらなる高感度検出を可能にしている10). さまざ まな誘導体化物質を用いた糖類のポストカラム法について は, Hondaによって総括されている11.

一方 Fox らは, 糖類の誘導体化を行わずに $[\mathrm{M}-\mathrm{H}]^{-}$を 直接測定する, HPLC-ESI タンデム質量分析 (MS/MS) 法 を用いた中性糖の分析を報告しており，誘導体化法と比較 すると高感度検出は難しいが, 数 $\mu \mathrm{g}$ 数百 $\mathrm{ng}$ 程度の検出 下限が得られている12). また Matthews らは, ギ酸アンモ ニウムを加えた移動相を用いることにより, 糖類にギ酸イ オンの付加した分子量関連イオンを検出し, 誘導体化を行 わない糖類の検出を可能にしている ${ }^{13)}$. さらに Buriova ら による移動相内の $\mathrm{Na}^{+}$を利用した $[\mathrm{M}+\mathrm{Na}]^{+}$を直接測定 する方法 ${ }^{14)}$, Rogatsky らによる $\mathrm{Cs}^{+}$を移動相に添加する ことにより $[\mathrm{M}+\mathrm{Cs}]^{+}$を直接測定する方法など15), 誘導体 化を行わない糖類の高感度検出を可能にしている。特に後 者は, 数 $\mathrm{pg}$ オーダーの高い検出感度が得られている.

いずれの方法も分離と検出の選択性という点において特 徵があるが, 試薬コストの問題, 誘導体化や試薬添加など の手間とそれらを使用することによる環境負荷の問題があ る。また, 糖の分離についてはいまだ改善されていない点 屯残っており, 検出感度の向上とと屯に分離の向上も糖分 析における課題である。本研究では, 単糖およびオリゴ糖 の LC/MS 法による簡便かつ高感度な分析法の開発を目的 として, 配位子交換カラムのセミミクロ化を行い, ESI 法 に基づく LC/MS 法の有用性を検討した。順相分配やイオ ン交換モードなどの分離カラムを用いた LC/MS 分析法の 例は多くあるが, 配位子交換モードによる LC/MS 法の報 告はほとんどない，配位子交換モードの分離は，糖の構造 異性体の分離に有用であることは知られているので，その セミミクロカラム化を達成することで LC/MS 法による糖 分析に用いた。ささらに糖分離後の溶出液に添加するアンモ 二アが，イオン生成効率を格段に向上させることを見いだ し, アンモニア濃度の検出感度に与える影響についても検 討することによって，質量分析条件の最適化を行った．配 位子交換カラムでは移動相に水のみしか使用することがで きないが，カラム分離後の溶出液に合流する 2 流路系を設 定することにより, アンモ二アを添加することを可能にし た。 また, それらの結果を従来の順相分配法による検出感 度と比較することで, 配位子交換 LC/MS 法の有用性を確 認した。 さらに，ここで開発した分析法を用いて，海藻か ら抽出した糖類の分析を行った。すすなわち海藻の一種であ るスジノリを用いて, 水熱反応によって得られる多糖類の
抽出, つづく加水分解によって得られる単糖およびオリゴ 糖を本法を用いて分析した。この実験によって数種類の単 糖が高い濃度で検出され, 本分析法を用いた実試料中の糖 類の定性㧍よび定量が可能であることを実証した。

\section{2. 実験}

\section{1 試 薬}

多重周回飛行時間型質量分析計のモデルを Fig. 1 に示 す.このモデルは反射型飛行時間型質量分析計に周回飛行 部が付いたあのである.

本研究では, 単糖㧍よびオリゴ糖として, D(+)-グルコー ス, ガラクトース, $\mathrm{D}(+)$-マンノース, $\mathrm{D}(-)$-フルクトース, $\mathrm{D}(+)$-キシロース, $\mathrm{D}($-)-アラビノース, $\alpha-\mathrm{L}(+)$-ラムノー ス, サッカロース, ラクトース, $\mathrm{D}(+)$-セロビオース, マル トース, D(+)-ラフィノース, マルトトリオース（いずれも 和光純薬工業(株)製) を分析に用いた。これらの単糖扔よ びオリゴ糖はすべて $100 \mathrm{mM}$ の水溶液として調製後, 適 宜希釈してその $10 \mu \mathrm{L}$ をカラムに注入した. アンモ二ア水 (25\%) 抒よびアセトニトリルはいずれも市販の試薬特級を 使用し，水は Milli-Q システムにより精製したものを用い た.

\section{2 装置および分析条件}

LC の送液部に, PU-980 (日本分光(株)製) を用い, 恒 温槽としてNANOSPACE SI-1/2004（(株)資生堂製）を 用いた。検出器には, 質量分析計 (VG Quattro II, micromass 社製）を接続して用いた。配位子交換モードの分離 カラムとして, スルホン酸型ポリスチレン系カチオン交換 樹脂（Ca 型）（平均粒子径 $10 \mu \mathrm{m}$ ）を, 高圧スラリー法に よりステンレス管 $(2.0 \mathrm{~mm}$ i.d. $\times 250 \mathrm{mmol})$ に充填したセ ミミクロカラム (ULTRON PS-80C/10S, 信和化工(株) 製）を新たに開発し，実験に用いた。移動相として水を用 い, 流量を $0.05 \mathrm{~mL} / \mathrm{min}$ とした。一方, 比較実験を行うた めの順相分配モードの分離カラムとして, アミノプロピル シリカ（平均粒子径 $5 \mu \mathrm{m}$ ）を, 高圧スラリー法によりステ ンレス管 $(2.0 \mathrm{~mm}$ i.d. $\times 250 \mathrm{mmol})$ に充填したセミミクロ カラム (ULTRON NH2/5S，信和化工(株)製）を用いた。 移動相として 75\%（v/v) アセトニトリルを用い，流量を $0.2 \mathrm{~mL} / \mathrm{min}$ とした。いずれの分離モードの場合にも，あ う1 台の送液ポンプを用いて $12 \%$ アンモニア水溶液を送 液し, カラム分離後の移動相と合流させるため, 移動相と の流量比を $5: 1$ に設定して, 移動相に対する最終的なア ンモニア濃度が $2 \%$ になるよな 2 流路系を設定した。質 量分析計のイオン化法としてェレクトロスプレーイオン化 (ESI) 法を用い, ESI法に打けるイオン源温度を $90^{\circ} \mathrm{C}$, キャピラリー電圧を $2.5 \mathrm{kV}$ に設定したうえで, 負イオン モードでマススペクトルを記録した。 マススペクトルの測 定質量範囲は $m / z 50 \sim 700$, スキャン時間を 1 秒とした。 また, 選択イオンモニタリング (SIM) モードによる定量下 限の測定では, すべての単糖抢よびオリゴ糖から負イオン モードによって得られる $[\mathrm{M}-\mathrm{H}]^{-}$を最適イオン種とする マスクロマトグラムより算出した。 


\section{3 海藻中の糖類の分析}

本分析法の応用例として, 海澡から水熱抽出によって得 られた糖類を分析の対象とした。水熱反応容器（容量 20 $\mathrm{mL}$ ) にスジノリ $0.2 \mathrm{~g}$ と水 $10 \mathrm{~mL}$ を入れ, 反応条件を設 定したオーブン内で処理した. すなわち, 昇温 $50^{\circ} \mathrm{C} / \mathrm{min}$, 反応時間 $30 \mathrm{~min}$ に設定し, 反応温度は $100 \sim 300^{\circ} \mathrm{C}$ の範 囲で $50^{\circ} \mathrm{C}$ 間隔で変化させて設定した，その後, 反応液をろ 過してろ液を回収し，こ机に酶酸エチルを加えて水層と有 機層とに分離した後, 水層部を分析に供した.

\section{3. 結果および考察}

\section{1 糖の分離とイオンモードの選択}

LC/MS 法では, 各糖類がごのようなイオン形態で検出 され，またどのようなイオン種をべースピークとするのか
という基本的な情報が必要である。本カラムを用いて，各 糖それぞれのESI法に打ける正イオンモードで質量スぺ クトルを測定したところ，イオン量が非常に少なく, ベー スピークとなるイオン種が特定できないことがわかった。 一方, 負イオンモードで質量スペクトルを測定したとこ ろ，[M-H] が分子量関連イオンとして検出されること がわかった，例として，負イオンモードを用いて分析して 得られた三糖のラフィノース，二糖のサッカロース，およ び単糖のグルコースのマススペクトルを Fig. 1 に示した. 図からわかるように, $[\mathrm{M}-\mathrm{H}]^{-}$をべースピークとするシ ンプルなスペクトルが得られた。すべての糖類についての マススペクトルを測定した結果を, 検出イオン種の相対強 度ととあに Table 1 にまとめた。単糖はすべて $[\mathrm{M}-\mathrm{H}]^{-}$ をベースピークとするシンプルなスペクトルが得られた

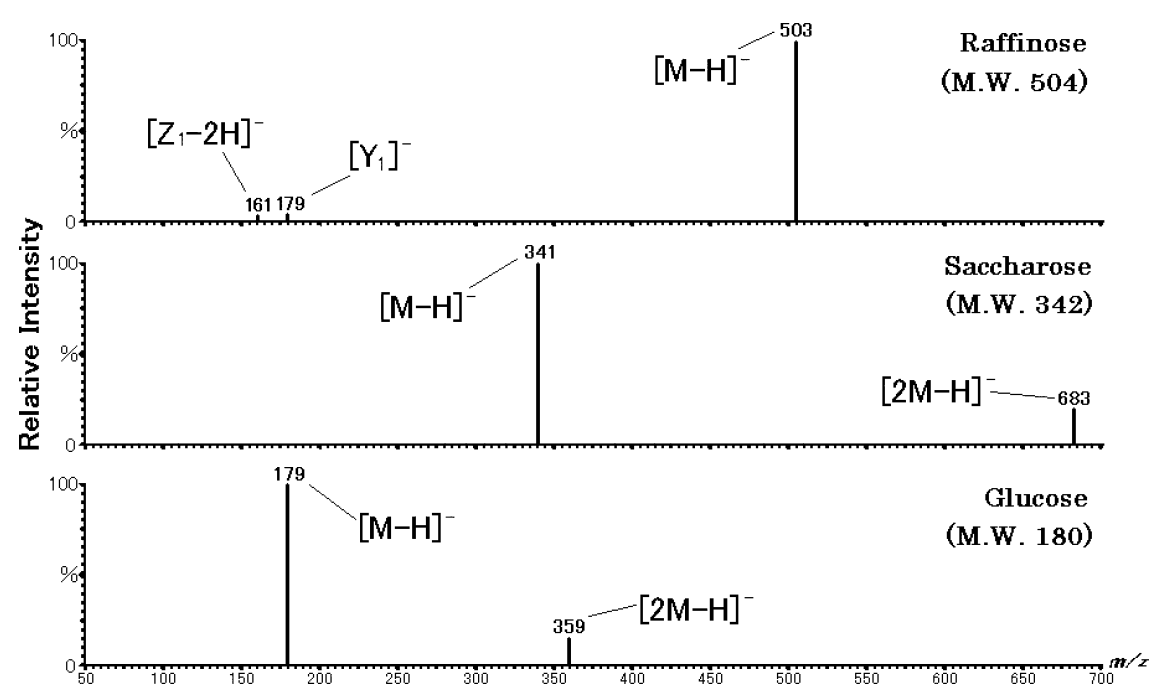

Fig. 1. Mass spectra of raffinose, saccharose, and glucose on negative ESI. LC conditions: column, ULTRON PS-80C/10S; column temperature, $70^{\circ} \mathrm{C}$; mobile phase, $\mathrm{H}_{2} \mathrm{O}$; flow rate, $0.05 \mathrm{~mL} / \mathrm{min}$. MS conditions: source temperature, $90^{\circ} \mathrm{C}$; capillary voltage, $2.5 \mathrm{kV}$; cone voltage, $20 \mathrm{~V}$. Sample concentration, $100 \mu \mathrm{M}$ each.

Table 1. Relative Intensities of the Negative-Ions in ESI Mass Spectra of the Saccharides

\begin{tabular}{|c|c|c|c|c|c|}
\hline \multirow{2}{*}{ Sugar } & \multicolumn{5}{|c|}{$\mathrm{m} / z$ [relative intensity (\%)] } \\
\hline & {$[\mathrm{M}-\mathrm{H}]^{-}$} & {$[2 \mathrm{M}-\mathrm{H}]^{-}$} & {$\left[\mathrm{Z}_{1}-2 \mathrm{H}\right]^{-}$} & {$\left[\mathrm{Y}_{1}\right]^{-}$} & {$\left[\mathrm{Y}_{2}\right]^{-}$} \\
\hline \multicolumn{6}{|l|}{ Trisaccharides } \\
\hline Raffinose & $503(100)$ & & & $179(4.5)$ & $341(4.5)$ \\
\hline Maltotriose & $503(98)$ & & $161(100)$ & $179(28)$ & $341(58)$ \\
\hline \multicolumn{6}{|l|}{ Disaccharides } \\
\hline Saccharose & $341(100)$ & $683(20)$ & & & \\
\hline Cellobiose & 341 & $683(16)$ & $161(100)$ & $179(32)$ & \\
\hline Maltose & $341 \quad(38)$ & $683(20)$ & $161(100)$ & $179(43)$ & \\
\hline Lactose & $341 \quad(49)$ & $683(18)$ & $161(100)$ & $179(33)$ & \\
\hline \multicolumn{6}{|c|}{ Monosaccharides } \\
\hline Glucose & 179 (100) & 359 (15) & & & \\
\hline Xylose & $149(100)$ & $299(13)$ & & & \\
\hline Galactose & $179(100)$ & $327(9.3)$ & & & \\
\hline Mannose & $179(100)$ & $359(17)$ & & & \\
\hline Rhamnose & $163(100)$ & $359(19)$ & & & \\
\hline Arabinose & $149(100)$ & $299(14)$ & & & \\
\hline Fructose & $179(100)$ & $359(10)$ & & & \\
\hline
\end{tabular}

LC conditions: column, ULTRON SP-80C/10S; column temperature, $70^{\circ} \mathrm{C}$; mobile phase, $\mathrm{H}_{2} \mathrm{O}$; flow rate, $0.05 \mathrm{~mL} / \mathrm{min}$; detection, MS detection using ESI-MS interface in the negative mode; source temperature, $90^{\circ} \mathrm{C}$; capillary voltage, $2.5 \mathrm{kV}$; cone voltage, $20 \mathrm{~V}$; sample concentration, $100 \mu \mathrm{M}$ each. 
が，サッカロース以外の二糖およびマルトトリオースで は，イオン源内でグリコシド結合が開裂して生じたと思わ れるフラグメントイオン $(m / z 161,179,341)$ が強い強度 で観察され, $[\mathrm{M}-\mathrm{H}]^{-}$の強度は相対的に低かった.オリゴ 糖の開裂によって生じるフラグメントイオンの表記の仕方 は, Costelloらによって示された命名法16) を参考にし た。 その開裂の図をFig. 2 に示した。 三糖ではいずれも $[\mathrm{M}-\mathrm{H}]^{-}$をほぼベースピークとするが，マルトトリオー スでは $\left[\mathrm{Z}_{1}-2 \mathrm{H}\right]^{-}$のフラグメントイオン $(\mathrm{m} / \mathrm{z} 161)$ の強 度が最も高かった。 以上のことから, 構成糖の違いによる イオン化のパターンに違いがあることが明らかになった。 理由は明らかになっていないが, 構成糖の違いが, オリゴ 糖がイオン化する際の分解のしやすさにかかわっているの ではないかと考えられる。

糖類 13 種の試料について, 負イオンモードを用いて詳 細な保持時間がわかるように単独分析を行い, その結果得 られたマスクロマトグラムを Fig. 3 に示した. 単糖はその ほとんどが異なる保持時間で検出され, マスクロマトグラ ム上区別して検出することが可能であった。 しかしなが ら, ガラクトースおよびマンノースは異なる保持時間で検 出されたものの, その差は小さく, 試料中に混合して存在 している場合にはマスクロマトグラムでも区別することが 難しい. また，二糖および三糖においても同様に，保持時 間は異なるものの, 混合液中での各々の分離は難しかっ た.この結果は, 従来の汎用型 $\mathrm{Ca}$ 型配位子交換カラムで あ同様に観察されてきた結果であり, セミミクロ化したこ とによって格段に解決するあのではなかった。このよう に, 分離上の課題はいくつか残ったあのの, 14 分以内で全 成分を溶出することができた。

\section{2 移動相添加物の最適化}

配位子交換クロマトグラフィーの最大の特徵は, 移動相
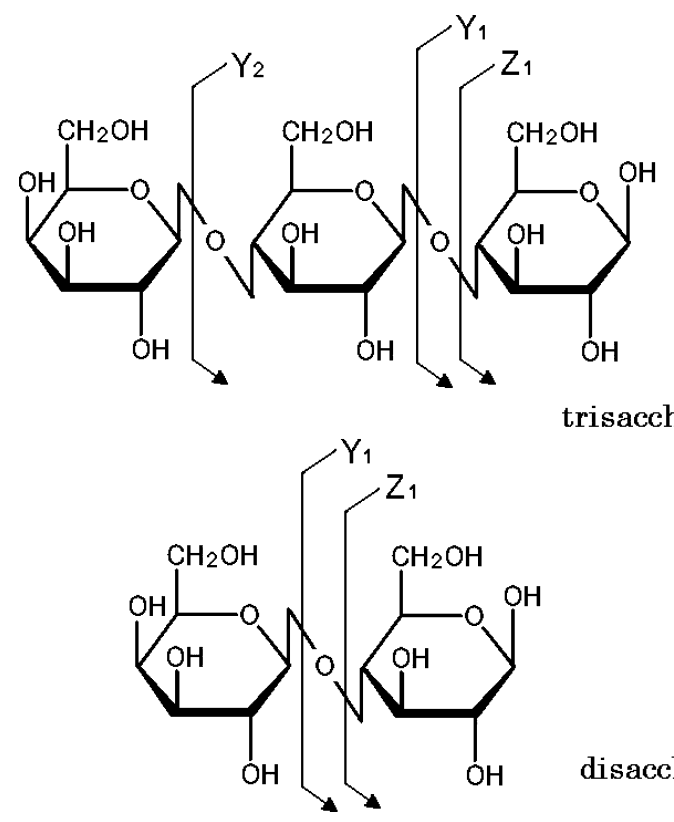

trisaccharide

disaccharide

Fig. 2. Types of di- and tri-saccharides fragmentation. ${ }^{16)}$
として水しか使用できないことである。そのため，イオン 化効率の向上やポストカラム誘導体化を目的として移動相 に溶媒や試薬などを添加することができない. しかしなが

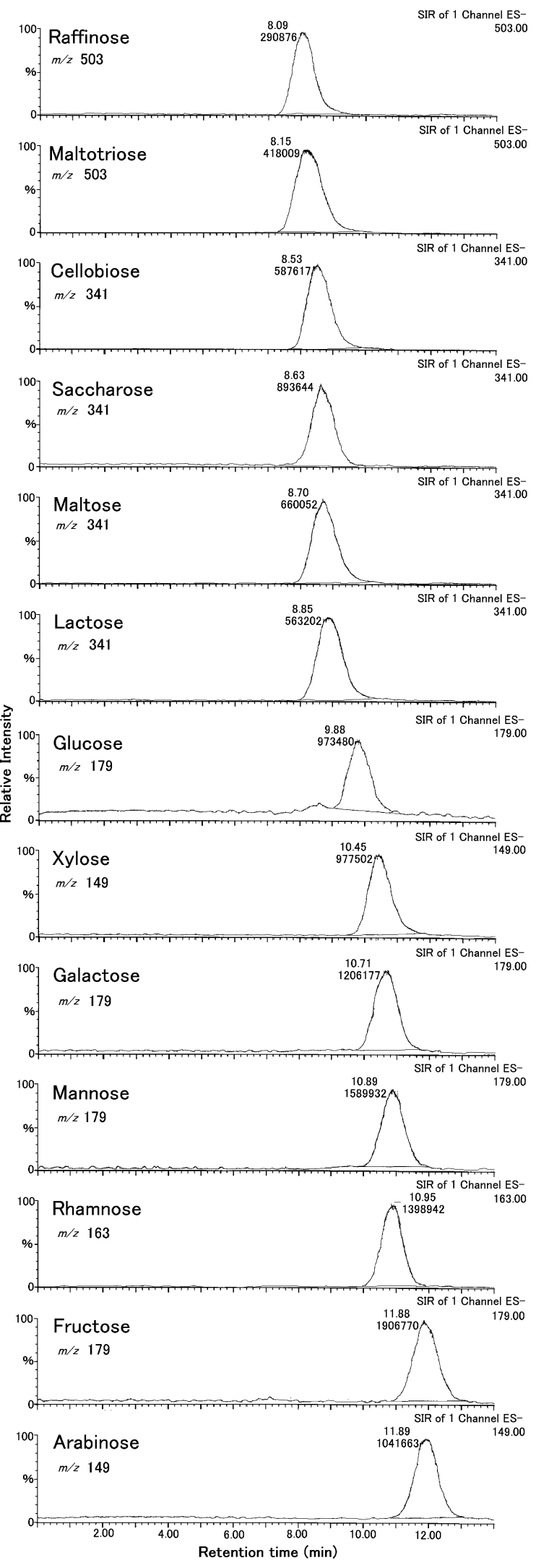

Fig. 3. Mass chromatograms of 13 saccharides on negative ESI. LC and MS conditions were the same as Fig. 1. SIR: selected ion recording. 
ら，移動相自身のイオン化屯抑えられるためバックグラウ ンドが低く, 目的物質のイオン化効率に基づいた検出がで きる，糖分子は，水を移動相として負イオンモードで一定 量の感度を保持できるが, さらにイオン化効率を向上させ 検出感度を向上させることを目的として, 糖分離後直ちに 質量分析部に導く流路と溶出液にアンモ二ア水を添加して 合流する 2 流路系を設定した。 また, 添加したアンモニア による検出感度の向上を確認するため, メ夕ノールおよび アセトニトリルを用いて同様の実験を行い, 添加物の種類 や濃度が糖のイオン化効率に与える影響について, グル コースを用いて検出感度を比較した。

アンモニア, メタノール, 拈よびアセトニトリルの移動 相添加後の濃度を, アンモ二アの場合は $1,2,5 \%(\mathrm{v} / \mathrm{v}), \times$ タノールおよびアセトニトリルの場合は $1,2,5,10,15$, $30 \%(\mathrm{v} / \mathrm{v})$ とそれぞれ設定して分析した場合の, グルコー スの検出感度を比較した (Fig. 4). その結果, アンモニア濃

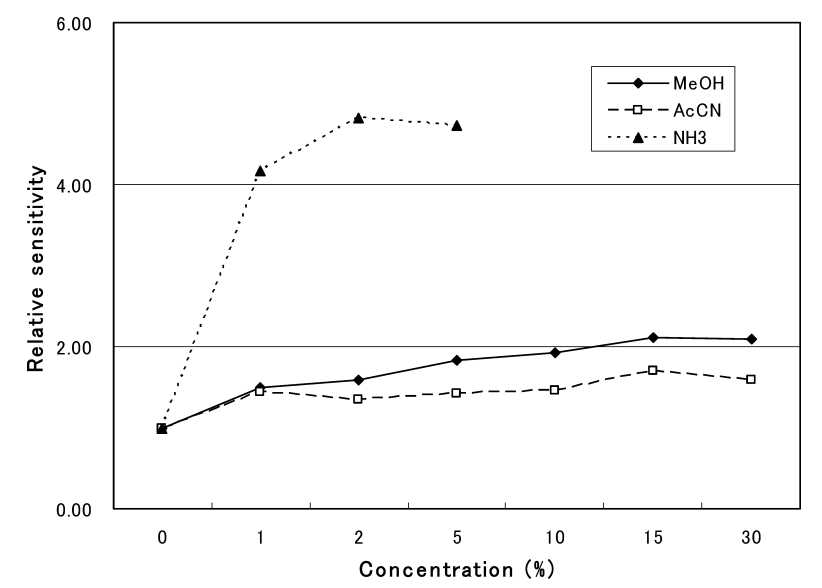

Fig. 4. Effect concentration of $\mathrm{MeOH}, \mathrm{AcCN}$ or ammonia added to mobile phase on the ion intensity of $[\mathrm{M}-\mathrm{H}]^{-}$of glucose. LC conditions: column, flow injection analysis; mobile phase, $\mathrm{H}_{2} \mathrm{O}$; flow rate, $0.01 \mathrm{~mL} / \mathrm{min}$. MS conditions were the same as Fig. 1.
度を $2 \%$ とした場合に最む検出感度が高く, それ以上濃度 を高くしても感度は上昇しなかった。また，メタノールや アセトニトリルを加えた場合には, 若干の感度向上は見ら れたものの, アンモ二アを添加した場合のほうが, はるか に検出感度が高かったため, 本研究では移動相およびアン モニア水の流量比を $5: 1$ に設定し, 合流後のアンモニア 濃度を $2 \%$ とした。 アンモ二ア濃度によって検出感度に極 大值をもつ理由としては, アンモニアの添加により $\mathrm{OH}^{-}$ が試料分子から脱プロトンすることによって負イオン効率 が向上するが，アンモニアが一定濃度を超えると $[\mathrm{M}-\mathrm{H}]^{-}$量の生成が飽和に達するためではないかと考え られる。

\section{3 カラム温度の最適化}

樹脂系のカラムでは温度が分離に影響を及ぼすパラメー 夕ーの一つであるため, カラム温度を変化させることに よって, 成分分離の向上を試みた。 カラム温度を $65 \sim$ $75^{\circ} \mathrm{C}$ の間で $5^{\circ} \mathrm{C}$ 間隔に設定したときの保持時間を比較した が, いずれのカラム温度においても各成分の保持時間の変

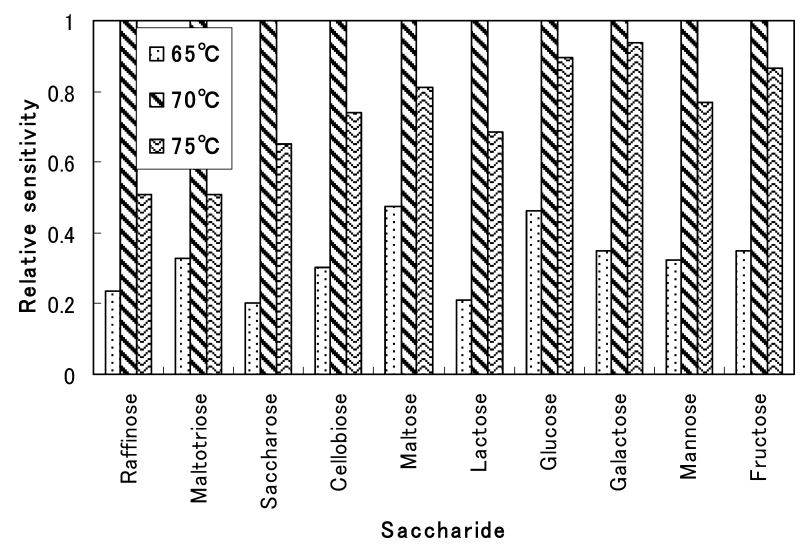

Fig. 5. Effect of column temperature on the ion intensity of $[\mathrm{M}-\mathrm{H}]^{-}$of each saccharides. LC and MS conditions were the same as Fig. 1 except for column temperature.

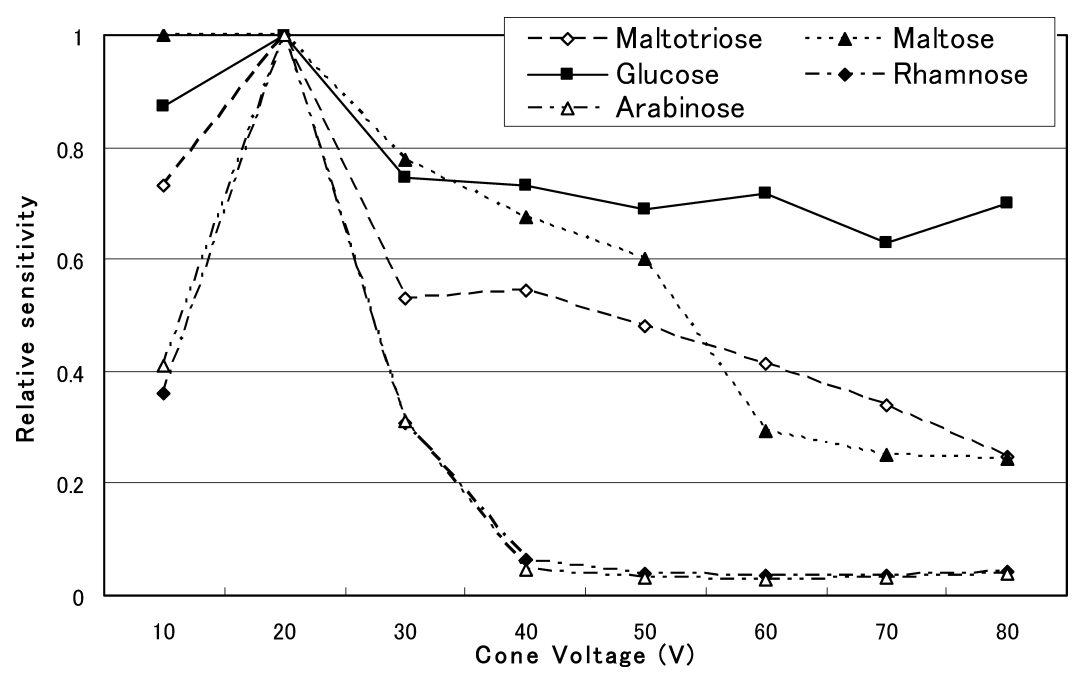

Fig. 6. Effect of cone voltage on the ion intensity of $[\mathrm{M}-\mathrm{H}]^{-}$of each saccharides. LC and MS conditions were the same as Fig. 1 except for cone voltage. 
化に大きな差は見られなかった。 しかしながら，検出感度 について, Fig. 5 に示すように若干ながら感度差をもたら すことがわかったので, 本研究ではカラム温度を $70^{\circ} \mathrm{C}$ と した。この理由は現段階では不明であるが， $70^{\circ} \mathrm{C}$ とう温 度は逆相系のカラムなどを使用する温度よりは高く, むし ろイオン源温度に近い.このような結果が現れた要因とし ては, カラム温度が試料の MS でのイオン化効率の向上と 何らかの関係があることが考えられるため, イオン源導入 時での移動相温度の違いがイオン化効率によ゙の程度影響を 与えるものか, 今後検討すべき課題である.

\section{4 コーン電圧の最適化}

ESI におけるイオン化効率の最適化にかかわる MS 条件 のパラメーターはいくつか存在するが, ここではイオン化 効率に特に影響を与えるコーン電圧について検討を行っ た.コーン電圧を $10 \sim 80 \mathrm{~V}$ の範囲で $10 \mathrm{~V}$ 間隔で設定し, 糖類 13 種類の $[\mathrm{M}-\mathrm{H}]^{-}$の相対強度を比較した. その結果 ほとんどの糖類で, コーン電圧を $20 \mathrm{~V}$ に設定したときに 最も検出感度が高くなることがわかった. Fig. 6 に, マル トトリオース, マルトース, グルコース, ラムノース, ア ラビノースの 5 種類を用いた結果を示した. これ以外の他 の糖類も,これら 5 種類と同様の結果が得られたことか

Table 2. Limits of Detection of Saccharides

\begin{tabular}{lc}
\hline Sugar & $\begin{array}{c}\text { SIM } \\
(\mathrm{pmol})\end{array}$ \\
\hline Raffinose & 0.05 \\
Maltotriose & 0.25 \\
Cellobiose & 1.25 \\
Saccharose & 0.50 \\
Maltose & 0.50 \\
Lactose & 1.25 \\
Glucose & 2.50 \\
Xylose & 1.25 \\
Galactose & 2.50 \\
Mannose & 2.50 \\
Rhamnose & 1.00 \\
Fructose & 2.50 \\
Arabinose & 1.25 \\
\hline
\end{tabular}

LC/MS conditions were shown in Table 1.
ら, 本研究ではコーン電圧を $20 \mathrm{~V}$ に設定することとした。

\section{5 単糖およびオリゴ糖の定量性および検出限界}

以上の検討結果より, LC/MS 条件を最適化したうえで, 負イオンモードによる各単糖およびオリゴ糖の定量性およ び検出限界を測定した。すべての単糖およびオリゴ糖につ いてそれぞれ個別に分析し，検量線を作成したところ，い ずれも5〜1,000 pmol の間で直線性の高い検量線（相関 係数：0.951〜0.999）が得られた. また, $100 \mathrm{pmol}$ での各 糖の保持時間およびピーク面積の再現性は, それぞれ 0.66 〜 1.20\%および 0.96〜2.86\%であった。

検出下限 $(S / N=3)$ については, すべての糖類において $[\mathrm{M}-\mathrm{H}]^{-}$を選択し, SIM モードにおける試料の注入絶対 量でまとめた。 それを Table 2 に示した。単糖ではいずれ 屯数 pmol のオーダーで検出が可能であり, オリゴ糖では 数百 fmol のオーダーで検出が可能であった.この值は,

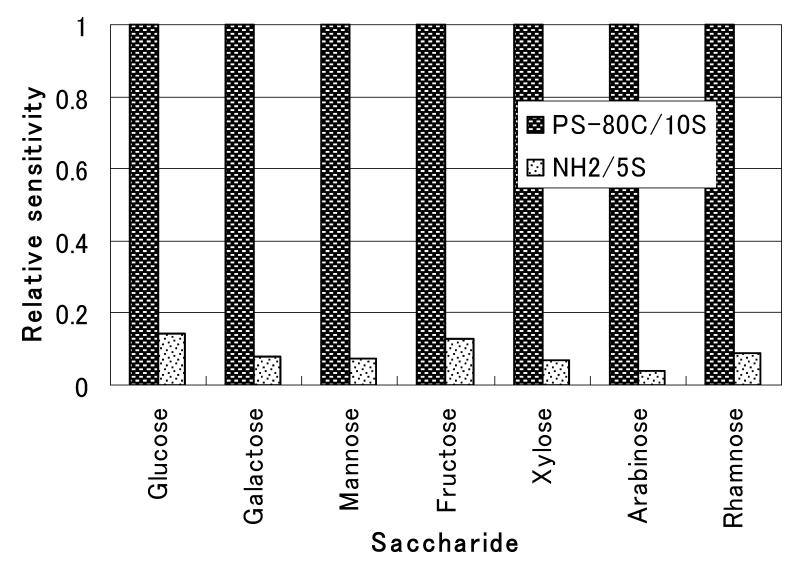

Fig. 7. Comparison of relative sensitivities of $[\mathrm{M}-\mathrm{H}]^{-}$ of each monosaccharides obtained by ligand exchange and normal phase LC/MS method. LC conditions for ligand exchange mode: column, ULTRON PS-80C/10S; column temperature, $70^{\circ} \mathrm{C}$; mobile phase, $\mathrm{H}_{2} \mathrm{O}$; flow rate, $0.05 \mathrm{~mL} / \mathrm{min}$. LC conditions for normal phase mode: column, ULTRON NH2/5S; column temperature, ambient; mobile phase, 75\% AcCN; flow rate, $0.2 \mathrm{~mL} / \mathrm{min}$. MS conditions were the same as Fig. 1.

Table 3. Retention Time and Separation Factor of Saccharides Using ULTRON PS-80C/10S

\begin{tabular}{|c|c|c|c|c|c|c|c|}
\hline \multirow{2}{*}{$\begin{array}{c}\text { Sugar } \\
\text { Raffinose }\end{array}$} & \multirow{2}{*}{$\begin{array}{c}\text { MW } \\
504.44\end{array}$} & \multirow{2}{*}{$\begin{array}{c}\begin{array}{c}\text { Monitoring } \\
\text { ion }(m / z)\end{array} \\
{[\mathrm{M}-\mathrm{H}]^{-}(503)}\end{array}$} & \multirow{2}{*}{$\begin{array}{c}\begin{array}{c}\text { Retention time } \\
(\mathrm{min})\end{array} \\
8.09\end{array}$} & \multicolumn{2}{|c|}{$k\left(t_{0}=6.09\right)$} & \multicolumn{2}{|c|}{$\alpha$} \\
\hline & & & & $k_{1}$ & 0.328 & & \\
\hline Maltotriose & 504.44 & {$[\mathrm{M}-\mathrm{H}]^{-}(503)$} & 8.15 & $k_{2}$ & 0.338 & $k_{2} / k_{1}$ & 1.030 \\
\hline Cellobiose & 342.30 & {$[\mathrm{M}-\mathrm{H}]^{-}(341)$} & 8.53 & $k_{3}$ & 0.401 & $k_{3} / k_{2}$ & 1.184 \\
\hline Saccharose & 342.30 & {$[\mathrm{M}-\mathrm{H}]^{-}(341)$} & 8.63 & $k_{4}$ & 0.417 & $k_{4} / k_{3}$ & 1.041 \\
\hline Maltose & 342.30 & {$[\mathrm{M}-\mathrm{H}]^{-}(341)$} & 8.70 & $k_{5}$ & 0.429 & $k_{5} / k_{4}$ & 1.028 \\
\hline Lactose & 342.30 & {$[\mathrm{M}-\mathrm{H}]^{-}(341)$} & 8.85 & $k_{6}$ & 0.453 & $k_{6} / k_{5}$ & 1.057 \\
\hline Glucose & 180.16 & {$[\mathrm{M}-\mathrm{H}]^{-}(179)$} & 9.88 & $k_{7}$ & 0.622 & $k_{7} / k_{6}$ & 1.373 \\
\hline Xylose & 150.13 & {$[\mathrm{M}-\mathrm{H}]^{-}(149)$} & 10.45 & $k_{8}$ & 0.716 & $k_{8} / k_{7}$ & 1.150 \\
\hline Galactose & 180.16 & {$[\mathrm{M}-\mathrm{H}]^{-}(179)$} & 10.71 & $k_{9}$ & 0.759 & $k_{9} / k_{8}$ & 1.060 \\
\hline Rhamnose & 164.16 & {$[\mathrm{M}-\mathrm{H}]^{-}(163)$} & 10.89 & $k_{10}$ & 0.788 & $k_{10} / k_{9}$ & 1.039 \\
\hline Mannose & 180.16 & {$[\mathrm{M}-\mathrm{H}]^{-}(179)$} & 10.95 & $k_{11}$ & 0.798 & $k_{11} / k_{10}$ & 1.013 \\
\hline Fructose & 180.16 & {$[\mathrm{M}-\mathrm{H}]^{-}(179)$} & 11.88 & $k_{12}$ & 0.951 & $k_{12} / k_{11}$ & 1.191 \\
\hline Arabinose & 150.13 & {$[\mathrm{M}-\mathrm{H}]^{-}(149)$} & 11.89 & $k_{13}$ & 0.952 & $k_{13} / k_{12}$ & 1.002 \\
\hline
\end{tabular}

LC/MS conditions were shown in Table 1. 


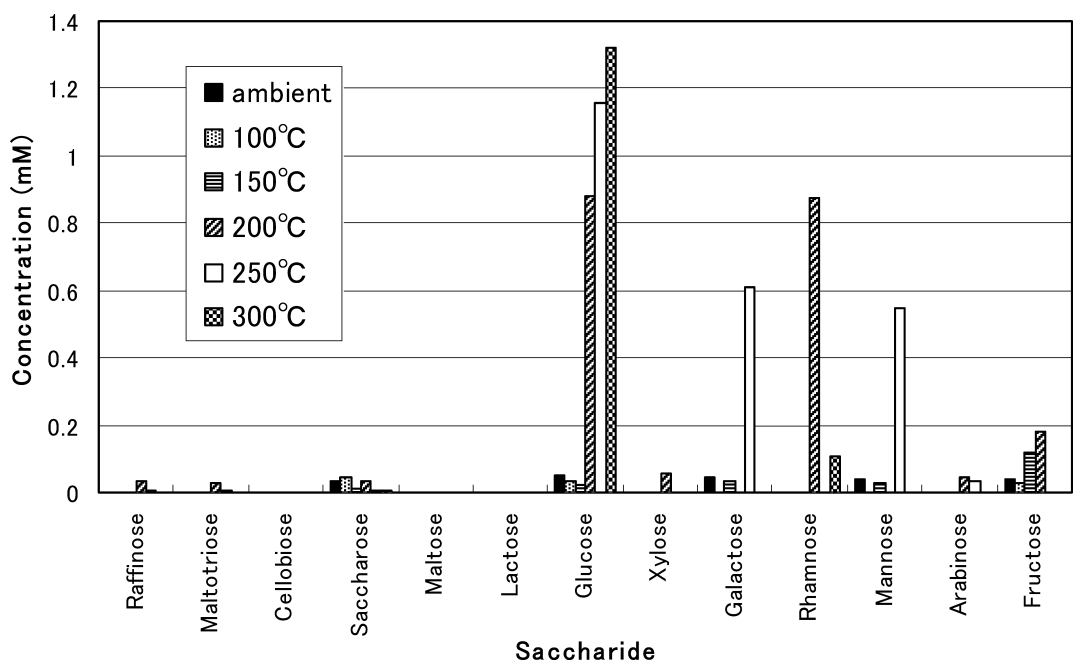

Fig. 8. Saccharides in seaweed, Ulva prolifera, which were extracted and hydrolyzed by hydrothermal reaction. LC and MS conditions were the same as Fig. 1.

従来の誘導体化法を用いた LC/MS 法による糖分析と比較 して，同等レベルか少し高い值が得られて抢り，本法が誘 導体化法と比べて簡便な方法であることから, 単糖および オリゴ糖の高感度分析法として有効であることが示され た.

\section{6 順相分配モードとの比較}

順相分配モードは従来から糖分析に広く用いられている 分離モードであり, 早くからセミミクロカラムの開発も行 われているので, ここでは, 本法で用いた配位子交換セミ ミクロカラムの有用性を実証するうえで， 2 種のカラムを 用いて分離抢よび検出感度の比較を行った. 各セミミクロ カラムで分析条件をそれぞれ最適化した後，各モードにお ける保持時間および分離係数を求めた。 本法の配位子交換 セミミクロカラムでの保持時間および分離係数を, Table 3 にまとめた。両モードの保持時間抢よび分離係数につい て比較したところ，いずれも大きな差は見られなかった が，配位子交換モードのほうがピーク形状はよく理論段数 あ高かった，検出感度について比較したところ，すべての 単糖において, 配位子交換モードのほうが順相分配モード より屯高い検出感度が得られることがわかった。 単糖 7 種 について, 各分離モードで検出された面積值を成分ごとに 相対的に表示した (Fig. 7)。 その相対比は成分によって多 少異なるが, 約 10〜20 倍の感度差が観察された。 その理 由としては，4.2 項で検討したように，移動相組成に基づ くイオン化効率が要因であると考えられる. 配位子交換 モードでは, 移動相の水に加えてアンモニアの添加によっ て $\mathrm{OH}^{-}$による試料分子からのプロトン脱離が起きやす く, $[\mathrm{M}-\mathrm{H}]^{-}$の生成が効率的にうながされることによっ て検出感度を上昇させたが，順相モードではアセトニトリ ルを用いるため, 糖のイオン量としては相対的に減少した と考えら机る.

\section{7 海藻中の単糖およびオリゴ糖の分析}

本法の実試料に対する有効性を確認するための応用例之 して, 海藻の水熱処理によって得られる試料中の単糖およ
びオリゴ糖の測定を行った，水熱反応の温度を常温および $100 \sim 300^{\circ} \mathrm{C}$ の間で $50^{\circ} \mathrm{C}$ 間隔に設定し，それぞれの条件で 生成する中性糖の生成量を測定した。海藻にはスジノリ (Ulva prolifera)を用いた。 分析の結果を Fig. 8 に記した. 図からわかるように，二糖および三糖はほとんど検出され ず，グルコースをはじめとした単糖が大量に検出された。 さらにグルコースに関しては, $200^{\circ} \mathrm{C}$ 以上で水熱反応を 行った場合, 反応温度の上昇とともに生成量も上昇してい くことが観察されたことから，反応温度と生成量との間に 明らかな相関性があると考えられる。最終的には，海藻中 に含まれる多糖類の水熱加水分解によって, 生成量や生成 糖を明らかにしていくことが目的であるが，現段階では， 水熱反応の条件によって生成する単糖の種類や濃度変化の 追跡が本法によって可能であったことから, 本法が寒試料 に対して十分に適用できることを確認できた。

以上本研究では, 配位子交換モードのセミミクロカラム の開発とアンモニア添加法によって, 単糖およびオリゴ糖 に対する ESI-LC/MS 分析法を確立し, 検出感度抢よび定 量性の面から実用的に応用可能であることが示唆された。 分離上はいまだ課題が残されているが，ESI 法によって単 糖およびオリゴ糖のいずれの場合であ $[\mathrm{M}-\mathrm{H}]^{-}$として検 出することが可能であり，さらに実試料分析に対してあそ の有用性が確認できたことから, 定量性のある分析法とし て技術的に貢献できるものと思わ机る。

\section{文献}

1) 戸井田敏彦，ぶんせき(Bunseki), 369, 504 (2005).

2) 戸井田敏彦, ファルマシア (FARUMASHIA), 40, 313 (2004).

3) N. Kawasaki, S. Itoh, M. Ohta, and T. Hayakawa, Anal. Biochem., 316, 15 (2003).

4) N. Kawasaki, M. Ohta, S. Itoh, M. Hyuga, S. Hyuga, and T. Hayakawa, Biologicals, 30, 113 (2002).

5) M. Fuchigami, J. Food Sci., 55, 739 (1990).

6) H. Garna, N. Mabon, B. Wathelet, and M. Paquot, Commun. Agric. Appl. Biol. Sci., 68, 297 (2003). 
7) 常定 健, 竹原淳彦, 光石一太, 井原俊英, 分析化学 (Bunseki Kagaku), 49, 437 (2000).

8) D. B. Gomis, D. M. Tamayo, and J. M. Alonso, Anal. Chim. Acta, 436, 173 (2001).

9) S. Suzuki, K. Kakehi, and S. Honda, Anal. Chem., 68, 2073 (1996).

10) J. Yuan, N. Hashii, N. Kawasaki, S. Itoh, T. Kawanishi, and T. Hayakawa, J. Chromatogr. A, 1067, 145 (2005).

11) S. Honda, J. Chromatogr. A, 720, 183 (1996).

12) D. S. Wunschel, K. F. Fox, A. Fox, M. L. Nagpal, K. Kim, G. C. Stewart, and M. Shahgholi, J. Chromatogr. A, 776, 205 (1997).
13) M. Ramm, J-L. Wolfender, E. F. Queiroz, K. Hostettmann, and M. Hamburger, J. Chromatogr. A, 1034, 139 (2004).

14) T. S. McIntosh, H. M. Davis, and D. E. Matthews, Anal. Biochem., 300, 163 (2002).

15) E. Rogatsky, H. Jayatillake, G. Goswami, and V. Tomuta, J. Am. Soc. Mass Spectrom., 16, 1805 (2005).

16) B. Domon and C. E. Costello, Glycoconj. J., 5, 397 (1988).

Keywords: Mono- and oligosaccharide, Electrospray ionization, Liquid chromatography/mass spectrometry (LC/MS), Semimicro column, Ligand exchange mode 